\title{
Flood Water Hydrochemistry Patterns Suggest Floodplain Sink Function for Dissolved Solids from the Songkhram Monsoon River (Thailand)
}

\author{
Tanapipat Walalite $^{1}$ (D) - Stefan C. Dekker ${ }^{1}$ - Floris M. Keizer ${ }^{1}$. Ignacy Kardel ${ }^{2}$. \\ Paul P. Schot ${ }^{1} \cdot$ Steven M. deJong ${ }^{3} \cdot$ Martin J. Wassen $^{1}$
}

Received: 15 September 2015 / Accepted: 27 August 2016/Published online: 13 September 2016

(C) The Author(s) 2016. This article is published with open access at Springerlink.com

\begin{abstract}
Although important for the eco-hydrological functioning of the floodplain, the interactions between river and floodplain are not well understood, especially for rivers in the tropical monsoon region. To explore the floodplain functioning of a tropical monsoon river system the longitudinal and transverse floodwater hydrochemical characteristics were studied in the Songkhram river (Thailand) and its floodplains. Water samples were taken during the monsoon period from 61 locations in the river and on its floodplain. Analysis of floodwater hydrochemistry revealed a significant decreasing longitudinal trend for most dissolved solids, attributable to geological differences. We also observed a significant decreasing transverse trend from river to floodplain. Nutrient concentrations revealed lower dissolved nitrogen, phosphate, and potassium concentrations on the floodplain than in the river channel, which suggests the floodplain functions as a sink for nutrients and chemical species in the river floodwater. This sink function may be related to the presence of a belt of bamboo separating the river from the floodplain, which seems to acts
\end{abstract}

Electronic supplementary material The online version of this article (doi:10.1007/s13157-016-0814-z) contains supplementary material, which is available to authorized users.

Tanapipat Walalite

t.walalite@uu.nl

1 Faculty of Geosciences, Copernicus Institute of Sustainable Development, Environmental Sciences, Utrecht University, P.O. Box $80.115,3508$, TC Utrecht, The Netherlands

2 Faculty of Civil and Environmental Engineering, Department of Hydraulic Engineering, Warsaw University of Life Sciences SGGW, ul. Nowoursynowska 159, 02-776 Warsaw, Poland

3 Faculty of Geosciences, Department of Physical Geography, Utrecht University, P.O. Box 80.115, 3508, TC Utrecht, The Netherlands as a sediment trap and nutrient filter, but this needs to be verified by additional dedicated research.

Keywords Ecological function · Bamboo - Spatial pattern $\cdot$ South-East Asia $\cdot$ Flood pulse concept $\cdot$ River continuum concept

\section{Introduction}

River floodplains are key elements in the landscape. Their numerous and diverse natural functions and ecosystem services include providing a refuge for many species (Ward et al. 1999; Tockner and Stanford 2002; Ward et al. 2002), river water purification (Costanza et al. 1998; Keddy et al. 2009), and flood storage and control (Banerjee et al. 2013; Grygoruk et al. 2013). The hydrology and ecosystem function of floodplains are highly dynamic (Junk et al. 1989; Bayley 1995; Ward et al. 1999; Ward and Tockner 2001). The extent, depth, and duration of inundation depend on the hydrology and local topography (Steiger and Gurnell 2003; Southwell and Thoms 2011; Langhans et al. 2013), while the chemistry of floodplain water is a function of exchange processes between groundwater and surface water and the influence of precipitation (Boulton et al. 1998; Doering et al. 2013; Keizer et al. 2014). Nutrient transport in the river-floodplain system is important for the productivity and species richness of floodplain vegetation.

The interactions and exchanges between the river and the floodplain during inundation, when water, sediment, and nutrients move across the floodplain, can be described by the flood pulse concept (FPC), which was originally proposed by Junk et al. (1989) and Junk and Wantzen (2004). The rewetting of dry sediment mobilizes nutrients and (in) organic matter from locally mineralized and decomposed organic 
matter (Baldwin and Mitchell 2000; McClain et al. 2003). In accordance with the FPC, it is assumed that river water covers the entire floodplain during inundation, producing a homogeneous hydrochemistry over the inundated floodplain. However, it has been shown for several floodplains that the water quality is not homogeneous across the floodplain. Distinct spatial patterns in inundation water quality have been observed for temperate river floodplains in Poland (Chormanski et al. 2011; Keizer et al. 2014) and Austria (Tockner et al. 1999). Large river floodplains located from the Arctic to the Amazon also demonstrate a zone of mixing between the sediment-rich river water and the local water (groundwater and/or precipitation), defined as the "perirheic zone" (Mertes 1997). The spatial heterogeneity in the floodplains is thought to result from the presence of different water sources and the impact of antecedent moisture conditions; in turn, these may cause various processes over time, such as decomposition of organic matter, solute transport, and absorption/desorption to/from soil (Wassen and Joosten 1996; Lewis et al. 2000; Beumer et al. 2008).

The transverse transport of material across floodplains is not the only process relevant for river-floodplain ecosystems: also important is longitudinal transport. The water quality can be altered downstream along the river channel by spatial differences in geological substrate that result in varying dissolved material input to the river channel. In turn, the concentrations of dissolved material such as nutrients may be increased or decreased when river water spreads over the floodplain, affecting the floodplain ecosystems (Lewis et al. 2000). The longitudinal patterns can be explained by using the river continuum concept (RCC) (Vannote et al. 1980), which assumes that physical gradients in the river from upstream to downstream are responsible for a continuum of change in ecological processes along the river. According to the RCC, nutrient input is mainly from organic material and is expected to vary downstream along the river because sources and forms of input vary, shading and turbidity affect the penetration of solar radiation into the water column, and the biotic community adapts in response. The physico-chemical variables that most influence the longitudinal patterns in the river channel are watershed area, phosphate concentration, total dissolved solids, solar radiation, annual precipitation, the ratio of stream length to watershed area, and terrestrial litter input (Cushing et al. 1983). However, the RCC does not describe ecological processes for rivers and floodplain combined, but mainly predicts ecological processes in river channels. Also, the hydrochemistry can vary along the river due to discontinued geomorphological characteristics (Sedell et al. 1989; Tockner et al. 2003).

Recently, Humphries et al. (2014) proposed a new concept to merge the longitudinal and the transverse processes in rivers and their floodplains, called the "river wave concept". This concept sees river flow characteristics as wave forms and characterizes them according to positions on the ascending or descending discharge limb, trough, and crest. These positions correspond to stages of water level in the river and floodplain. Longitudinal and transverse processes of the river and the floodplain ecosystems are a function of these positions, temporally and spatially.

To the best of our knowledge, unifying concepts that describe the hydrochemistry and ecological functioning of floodplains have not been tested for tropical monsoon rivers. Such rivers provide important environmental, economic, and social benefits to local communities, including biodiversity hotspots, agricultural land, and fresh water. However, existing knowledge of tropical monsoon river-floodplain systems is insufficient for their efficient conservation and management (Bayley 1995; Arthington et al. 2010). To improve understanding of the river-floodplain function in a tropical monsoon region, we examined the longitudinal and transverse spatial patterns of hydrochemistry, nutrient availability, and land cover along the Songkhram river, its tributaries and floodplain in north-eastern Thailand. The Songkhram monsoon river is characterized by a relatively natural flow, and can thus serve as a reference for tropical monsoon systems. In this research the following three questions were central: 1) What are the longitudinal (upstream-downstream) and transverse (river-floodplain) trends in hydrochemistry and nutrient availability during the flood period in the monsoon river system? 2) Do nutrient availability and water chemistry differ significantly between the main river channel and the floodplain during the flood period? 3) Are these differences related to land cover on the floodplain?

\section{Study Area}

The Songkhram river, a tributary of the Mekong River, is located in north-eastern Thailand (Fig.1). It is approximately $495 \mathrm{~km}$ long, drains an area of $13,000 \mathrm{~km}^{2}$ and its average discharge is $226 \mathrm{~m}^{3} \mathrm{~s}^{-1}$ during the monsoon season and $2.3 \mathrm{~m}^{3} \mathrm{~s}^{-1}$ during the dry season. Precipitation records from 1980 to 2010 at Ban Tha Kok Deang, centrally located in the catchment, show that annual precipitation averages $1960 \mathrm{~mm}$ and ranges from 1090 to $2880 \mathrm{~mm}$. The monsoon season lasts from May to September and is followed by a cool dry season from October to February that is succeeded by a hot dry season from March to April. During the monsoon season the average precipitation is $1690 \mathrm{~mm}$ (range 906-2420 $\mathrm{mm}$ ); this compares with an average precipitation of $270 \mathrm{~mm}$ (range 80 $490 \mathrm{~mm}$ ) during the dry season (figures compiled from daily data from the Department of Water Resources, Thailand). Mean annual temperature is $26^{\circ} \mathrm{C}$ and the warmest month is April $\left(35^{\circ} \mathrm{C}\right)$. The minimum temperature is around $15^{\circ} \mathrm{C}$ from December to January.

Extensive floodplains are found in the lower part of the basin as well as along the upper part of the river. These 


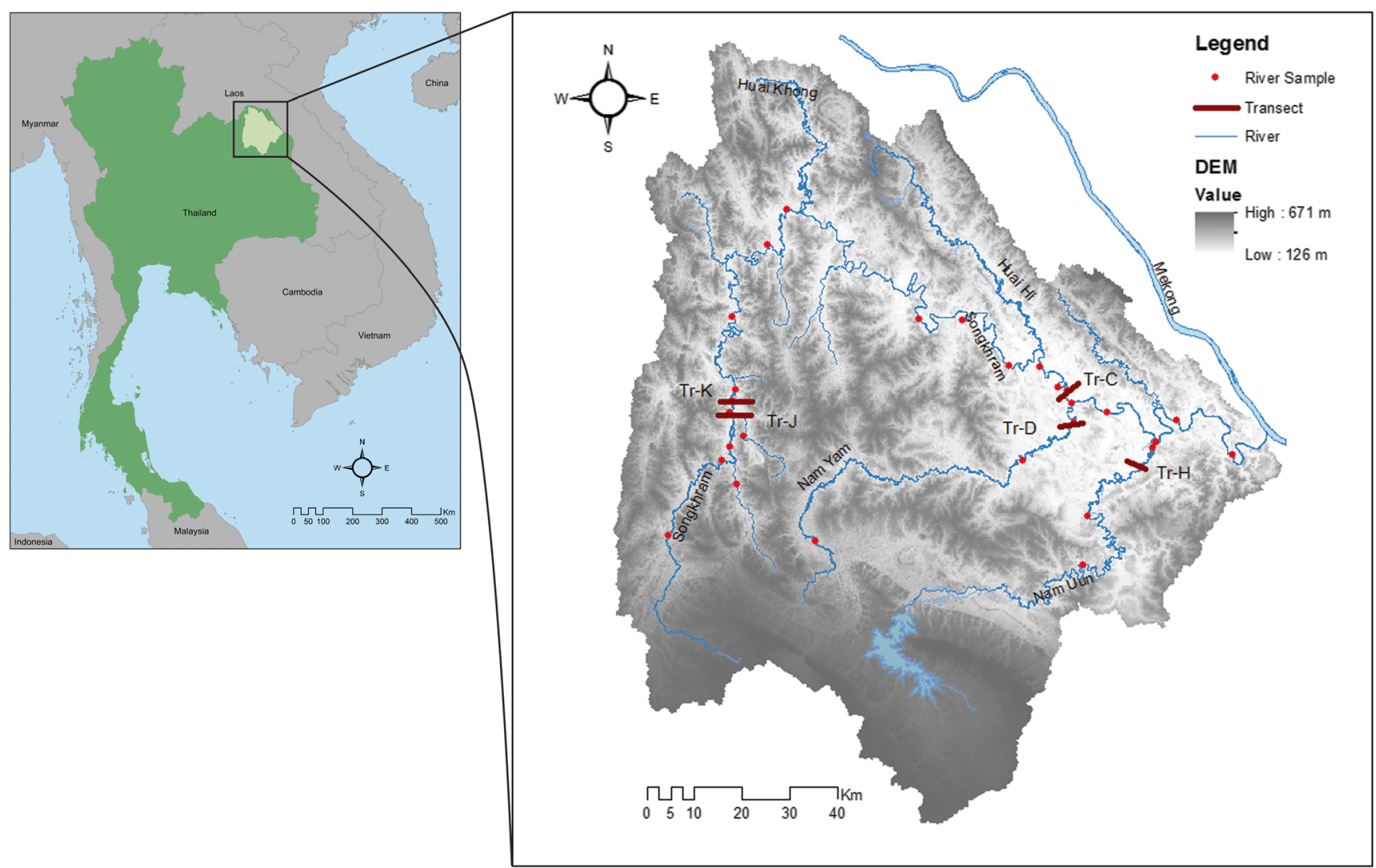

Fig. 1 Location of the Songkhram river catchment in north-eastern Thailand (left) and surface water network and elevation (right). Sample locations in the main river channel and the locations of each transect across the floodplains are shown in red dots. Transects $\mathrm{J}$ and $\mathrm{K}$ are located

inundate yearly due to high river discharges during the monsoon season and water backing up from the Mekong river (Blake et al. 2011). There are two major tributaries: the Nam-Yam and Nam-Uun. These join the main river in the lower basin. The river's discharge behavior is quite natural, as there are no large dams that regulate water flow in the main channel. The average area flooded annually in the lower basin, estimated using Landsat images from the period 2000 to 2006, is $760 \mathrm{~km}^{2}$ (Thiha and Wongpakam 2012).

The land uses in the Songkhram river catchment are agriculture (65\% of the area), forest $(20 \%)$, settlement $(5 \%)$, surface water $(5 \%)$, and other $(5 \%)$ (Land development Department 2014). The floodplain vegetation community is known as "Pa Bung Pa Taam" and is dominated by a dense thorny bamboo: Bambusa flexuosa (Blake et al. 2011; Khammongkol et al. 2013).

The geology of the catchment is characterized by sedimentary rocks, dominated by sandstone, siltstone, mudstone, and claystone of the Phu Thok formation (KTpt) of Cretaceous and Tertiary age. In the upstream area of the catchment, the Maha Sarakham formation (KTms) from mid-Cretaceous is found, containing a layer of readily soluble rock salt, gypsum, anhydrite, and potash. Alluvial in the upper course of the Songkhram river. Transects C, D and H are located in the lower courses of the Songkhram, Nam-Yam, and Nam-Uun rivers, respectively. Elevation is in meters relative to mean sea level, based on a Digital Elevation Model (USGS 2006)

deposits and terrace deposits are found on the floodplain, along the river channel: see Fig.2 (Department of mineral resources 2012).

\section{Methods}

\section{Floodwater Sampling}

During the monsoon season from 10 to 26 September 2013 we conducted a field campaign in the Songkhram river catchment to sample floodwater from the main river channel and along transects across the inundated floodplain. Samples were taken during the falling limb of the yearly flood curve: in September 2013 the average discharge of the Songkhram river was $1220 \mathrm{~m}^{3} \mathrm{~s}^{-1}$, whereas in August the average discharge had been $1660 \mathrm{~m}^{3} \mathrm{~s}^{-1}$ (Thailand Royal Irrigation Department 2016).

We visited a total of 107 locations distributed along the entire length of the river. Accessibility was important and therefore most were at or near a bridge. Some locations in the NamYam tributary were chosen because they could easily be reached by boat. The locations of the transects across the river floodplain were selected based on classification of floodwater 
Fig. 2 Geology of the Songkhram river catchment, dominated by sedimentary rock (Geological map of Thailand scale 1:250,000, Department of Mineral Resources, Thailand 2012)

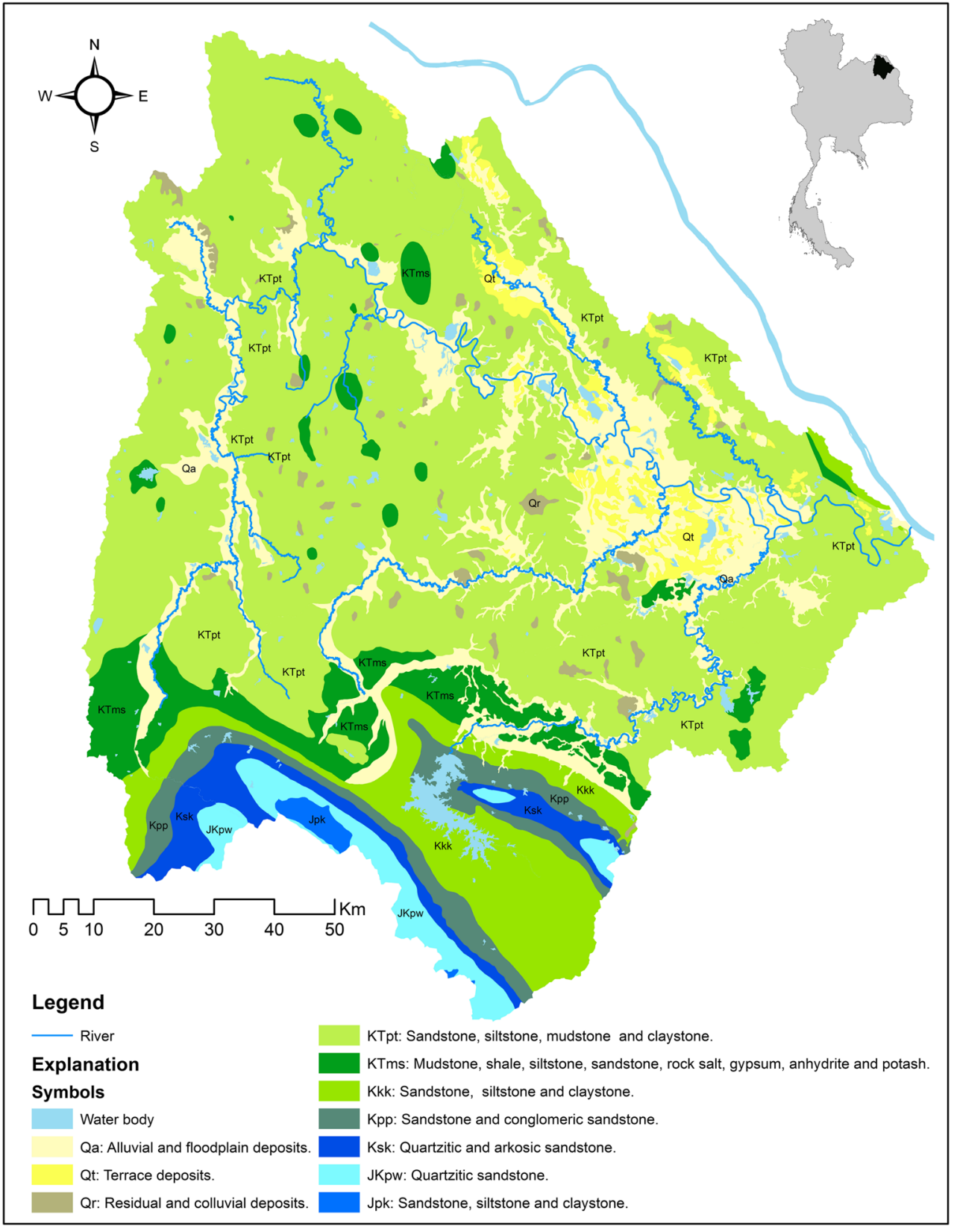

zones from a Landsat 8 image acquired on 13 August 2013, one month before the field campaign. Five transects were visited during the field campaign, three of which were in the lower basin: one across the Songkhram river (TR-C), one across the Nam-Yam river (TR-D), and one across the Nam-Uun river (TR-H). Two transects (TR-J and TR-K) were positioned across the Songkhram river in the upper basin (Fig. 1).

To select locations for water sampling, we measured electrical conductivity (EC), total dissolved solids (TDS), temperature, dissolved oxygen, and $\mathrm{pH}$ in situ using a YSI 556MPS Multi-parameter Instrument (YSI Environmental 2009) that had undergone maintenance service just prior to use. Every day $\mathrm{pH}$ and oxygen were calibrated before being measured.
Along each transect, water samples were taken in the river and at several locations across the inundated floodplain. In the floodplain zone, sampling locations were chosen in light of the EC measurements and the observed vegetation communities, so that the sampling sites captured the variation in the EC and vegetation communities.

In total, 73 water samples were taken from 61 of the 107 locations in the rivers and floodplains. Not all 107 locations were sampled because some locations were close to each other and on site EC measurement did not show notable differences. We used a Kemmerer type water sampler $10 \mathrm{~cm}$ in diameter and $30 \mathrm{~cm}$ long, with a rope attached to open the lid for underwater sample collection, and a stainless steel rod 
$20 \mathrm{~cm}$ long extending from the base of the bottle. At each sampling location $2000 \mathrm{ml}$ of water was collected at ca. $30 \mathrm{~cm}$ below the water surface, to avoid floating debris. Samples were taken from 33 locations in the river and 28 locations on the floodplain. In addition, to obtain insight into possible stratification in the water column, a second sample was collected at ca. $20 \mathrm{~cm}$ from the bottom at 12 locations (4 in river; 8 on floodplain). The vegetation and land use type around each sampling location were described.

The water samples were collected in a high-density polyethylene water container and stored immediately under dark conditions in a cooler on ice. The container was pre-washed on site, with the water to be sampled, before being filled with the sample. Within the same day of collection, the samples were transported to the laboratory of the Aquaculture Research Institute, Department of Fisheries, Ministry of Agriculture and Cooperatives in Sakon Nakhon, for filtration and treatment.

In the laboratory, within $24 \mathrm{~h}$ of the sampling, alkalinity was measured on a $5 \mathrm{ml}$ aliquot, using a chemical test kit (Merck KGaA 2013). A $250 \mathrm{ml}$ unfiltered water sample had been stored in a wide-mouthed Nalgene PE bottle $(250 \mathrm{ml})$ and treated with $2 \mathrm{ml} 0.05 \mathrm{M}$ sulfuric acid. These samples were analyzed for total phosphorus (TP) using persulfate oxidation digestion and spectrophotometry (Spectronic Genesys 20, Laboratory of Environmental Studies, Faculty of Environmental and Resource studies, Maha Sarakham University, Thailand).

From each water sample, $500-1000 \mathrm{ml}$ (depending on filtration speed) was filtered through a $1.2 \mu \mathrm{m}$ Whatman GF/C glass fiber filter. The filtrate was refiltered through a $0.45 \mu \mathrm{m}$ Whatman cellulose acetate membrane filter and an aliquot comprising the first $125 \mathrm{ml}$ of filtrate was then stored in a wide-mouth PE bottle $(125 \mathrm{ml})$, and $1 \mathrm{ml}$ of $65 \%$ nitric acid was added. An aliquot comprising the second $125 \mathrm{ml}$ of the filtrate was also stored in a wide-mouth PE bottle but was not acidified. Most samples were filtered on the day they were sampled; all samples were filtered within $48 \mathrm{~h}$ of collection in the field. The first and second aliquots of filtrate were kept under dark and cool conditions (approximately $4{ }^{\circ} \mathrm{C}$ ) for approximately 2 days until they were transported to the GEO lab of Utrecht University, the Netherlands. The samples were in transit for 8 days. Using inductively coupled plasma optical emission spectrometry (ICP-OES), the first aliquots were analyzed for the following major cations, trace elements, and metals: aluminum $\left(\mathrm{Al}^{3+}\right)$, barium $\mathrm{Ba}^{2+}$, calcium $\left(\mathrm{Ca}^{2+}\right)$, iron $\left(\mathrm{Fe}^{2+/ 3+}\right)$, potassium $\left(\mathrm{K}^{+}\right)$, magnesium $\left(\mathrm{Mg}^{2+}\right)$, manganese $\left(\mathrm{Mn}^{2+}\right)$, sodium $\left(\mathrm{Na}^{+}\right)$, silica $\left(\mathrm{Si}^{+}\right)$, strontium $\left(\mathrm{Sr}^{2+}\right)$, and zinc $\left(\mathrm{Zn}^{2+}\right)$. The second aliquots were analyzed for chloride $\left(\mathrm{Cl}^{-}\right)$, nitrate $\left(\mathrm{NO}_{3}{ }^{-}\right)$, nitrite $\left(\mathrm{NO}_{2}{ }^{-}\right)$and sulfate $\left(\mathrm{SO}_{4}{ }^{2-}\right)$, using ion chromatography. Ammonium $\left(\mathrm{NH}_{4}{ }^{+}\right)$and phosphate $\left(\mathrm{PO}_{4}{ }^{3-}\right)$ were analyzed by continuous segment flow analyzer (Seal Analytical 2000).

\section{Statistical Characterization of Floodwater Hydrochemistry}

To ascertain the variance of the hydrochemical parameters analyzed, a statistical overview was created showing the number, mean, minimum, maximum, range, standard deviation, and coefficient of variation of each parameter. To understand which combination of parameters accounted for the largest portion of the variance, we used principal component analysis (PCA) with the varimax rotation method performed on the standardized data. Next, factor scores of each sample were determined by means of regression analysis. This reduced the chemical variables to three main factors, which were determined by a parallel analysis method (Franklin et al. 1995; Peres-Neto et al. 2005). Total dissolved nitrogen (TDN) was calculated by the summation of nitrogen in $\mathrm{NH}_{4}{ }^{+}, \mathrm{NO}_{2}{ }^{-}$, and $\mathrm{NO}_{3}{ }^{-}$. There were some missing values in the $\mathrm{NO}_{3}{ }^{-}$dataset because concentrations were below the detection limit for some samples and some errors occurred when preparing samples. As PCA does not allow missing values, we first assumed that there was no $\mathrm{NO}_{2}{ }^{-}$and $\mathrm{NO}_{3}{ }^{-}$for the samples in question. Then we tested this assumption by only using $\mathrm{NH}_{4}{ }^{+}$as nitrogen and using the half values of the lowest detection limits for $\mathrm{NO}_{3}{ }^{-}$and $\mathrm{NO}_{2}{ }^{-}$. The subsequent PCA analysis did not reveal any significant differences. We did not include total dissolved solids (TDS) in the PCA since TDS is directly proportional to the measured EC.

\section{Determining Longitudinal and Transverse Trends}

Longitudinal (upstream-downstream) trends in hydrochemistry were analyzed by plotting the scores of the three principal components against the distance to the river catchment outlet, for samples taken in the river channel. The scores of the first principal component were also plotted on a map of the catchment, to analyze their spatial distribution in the Songkhram river and its tributaries. Transverse hydrochemical trends in the river-floodplain system were analyzed by plotting the scores of the three principal components against the distance of the floodplain sampling location from the main river channel. This was done for all transects together and also for each individual transect.

Differences between river channel and floodplain concentrations of the nutrients phosphorus, potassium, and nitrogen in floodwater were analyzed by comparing box plots for all river channel samples with box plots for all floodplain samples.

\section{Relationship between Floodplain Land Cover and Hydrochemistry}

To ascertain the relationship between floodwater hydrochemistry and land cover, the land cover under the 
flooded areas was analyzed by first estimating flood extent and then determining the land cover for that area.

To estimate the inundated area of floodplain we used satellite images of Landsat 7 ETM+ from 17 August 2000. Interpretation of the image of the upper part of the basin was hampered by cloud cover. Therefore the floodplain area we report on in this study refers to the lower part of the catchment only. The image, which has a spatial resolution of $30 \mathrm{~m}$, was visually interpreted and the flooded area was delineated using the ENVI 5.0 software package (Exelis Visual Information Solutions 2014). The date on which it was acquired, 17 August 2000, is in the third quartile of the highest precipitation records in the period 1980-2010. Thus we consider this image to be representative of average to high floods.

The land cover classification for the lower river basin was produced using a Landsat 8 OLI scene acquired on 3 January 2014 during the dry season. This image also has a spatial resolution of $30 \mathrm{~m}$. It was radiometrically corrected to the top-ofatmosphere reflectance image following the USGS guidelines (USGS 2013). Land cover was determined using a supervised classification approach with the maximum likelihood classifier (Lillesand et al. 2008). This approach utilizes representative samples of particular land cover classes of interest as training regions. The training region is an area of known land cover from ground truth data assigned to the corresponding pixel(s) in the image, which the software uses as a guideline when assigning land cover classes to similar image pixels. When selecting training regions we relied on information and experience acquired on the ground during fieldwork in February 2013.

The classification accuracy was estimated by randomly taking 330 locations in the classified image and comparing them with the land cover derived by visually interpreting a high-resolution satellite image available in Google Earth acquired on 10 January 2014. To estimate the accuracy of the supervised classification, a confusion matrix was computed; the matrix compares the classification result class with the actual class of land cover as determined by visual interpretation from Google Earth.

To determine the land cover characteristics of the lower basin floodplain area we superimposed the map of inundated area on the land cover class map.

\section{Results}

\section{Statistical Characterization of Flood Water Hydrochemistry}

Hydrochemical statistics of the sampled surface waters are summarized in Table 1. The chemistry of the water is dominated by alkalinity, $\mathrm{Cl}^{-}, \mathrm{Na}^{+}, \mathrm{Ca}^{2+}$, and $\mathrm{Si}^{+}$. On average, the coefficient of variance (CV) is $67 \%$ over the area, indicating general great variability between the samples. The most variability was found for $\mathrm{NH}_{4}{ }^{+}$and $\mathrm{Mn}^{2+}$, although concentrations were low. Low variability (CV less than $40 \%$ ) was found for temperature, $\mathrm{pH}$, dissolved oxygen, and some ions $\left(\mathrm{Ba}^{2+}, \mathrm{Fe}^{2+/ 3+}, \mathrm{Si}^{+}, \mathrm{Zn}^{2+}\right)$.

PCA revealed that the three main principal components explain $62 \%$ of the overall variance in water chemistry (Table 2). The first PCA component (accounting for $44 \%$ variance) contains most of the chemical variables, with factor scores above 0.7 for $\mathrm{EC}, \mathrm{Ca}^{2+}, \mathrm{Mg}^{2+}, \mathrm{HCO}_{3}{ }^{-}, \mathrm{Na}^{+}, \mathrm{Cl}^{-}, \mathrm{K}^{+}$, $\mathrm{SO}_{4}{ }^{2-}, \mathrm{Si}^{+}$, and $\mathrm{Sr}^{2+}$. We interpret this principal component as the enrichment of water with major ions resulting from weathering and dissolution of minerals.

The second PCA component (accounting for $10 \%$ variance) contains the variables $\mathrm{Zn}^{2+}$, TP, and $\mathrm{PO}_{4}{ }^{3-}$, which correlate negatively with dissolved oxygen levels. The presence of high TP and $\mathrm{PO}_{4}{ }^{3-}$ concentrations when dissolved oxygen is low indicates anaerobic and/or chemical reduction conditions during which $\mathrm{PO}_{4}{ }^{3-}$ is released to the water. Thus, we interpret this principal component as low redox conditions enhancing dissolution of phosphorus. It is notable that this condition was observed deeper in the water column, where dissolved oxygen is lower than at the surface.

The third PCA component (accounting for $8 \%$ variance) is associated with $\mathrm{Al}^{3+}$ and $\mathrm{Fe}^{2+, 3+}$, which we interpret as dissolution of aluminum and iron compounds from the soil.

\section{Longitudinal and Transverse Hydrochemical Trends}

Longitudinal trends in hydrochemistry were analyzed by plotting the scores of river samples on each principal component arranged from upstream to downstream (Fig. 3). Only the first component correlated significantly with the relative distance to the river outlet $(r=-0.59, p<0.05)$, indicating that the dissolved solids decreased in the downstream direction. The spatial distribution also shows higher scores in the upstream part of the Songkhram river and its tributaries, with lower scores in the downstream part (Fig. 4). This longitudinal trend is related to the geological substrate of the catchment (see Fig. 2). In the upstream area the river channel is cut into bedrock: the KTms formation that consists of rock salt, gypsum, anhydrite, and potash, while the main geological substrate of the floodplain is alluvium. The correlation between the smallest distances of the sample location to the $\mathrm{KTm}$ formation and the $\mathrm{PC} 1$ score was significant, with $r=-0.43(p<0.05)$. This implies that the concentration of dissolved material in the water is related to the distance from their geological origin.

For the transverse trends across the floodplains using all transects (Fig. 5), a significantly decreasing trend was observed for the first component. The scores of this component correlated significantly with the distance of each sampling location to the main river channel, with $r=-0.32(p<0.05)$. This means the concentration of major dissolved solids in the floodplain inundation water is inversely related to distance 
Table 1 Statistical summary of floodwater hydrochemical variables measured in the field and from floodwater sample laboratory analyses

\begin{tabular}{lllllllll}
\hline Variables & Units & $(\mathrm{n})$ & Mean & Min & Max & Range & SD & CV \\
\hline $\mathrm{EC}$ & $\mu \mathrm{S} / \mathrm{cm}$ & 118 & 73.19 & 12 & 309 & 297 & 51.11 & 0.7 \\
$\mathrm{TEMP}$ & ${ }^{\circ} \mathrm{C}$ & 116 & 31.09 & 24.16 & 40.86 & 16.7 & 2.05 & 0.07 \\
$\mathrm{pH}$ & $\mathrm{pH} u n i t s$ & 118 & 5.97 & 3.2 & 7.13 & 3.93 & 0.48 & 0.08 \\
$\mathrm{DO}$ & $\mathrm{mg} / \mathrm{L}$ & 112 & 4.87 & 0.01 & 9.97 & 9.96 & 1.62 & 0.33 \\
$\mathrm{TDS}^{2}$ & $\mathrm{mg} / \mathrm{L}$ & 116 & 46.97 & 8 & 201 & 193 & 32.96 & 0.7 \\
$\mathrm{Alkalinity}^{2}$ & $\mathrm{mg} / \mathrm{L}$ & 72 & 21.02 & 4.25 & 131.75 & 127.5 & 15.38 & 0.73 \\
$\mathrm{TP}^{2-}$ & $\mathrm{mg} / \mathrm{L}$ & 73 & 0.05 & 0.01 & 0.16 & 0.15 & 0.03 & 0.63 \\
$\mathrm{PO}_{4}{ }^{3-}$ & $\mathrm{mg} / \mathrm{L}$ & 73 & 0.02 & 0.004 & 0.15 & 0.15 & 0.02 & 0.93 \\
$\mathrm{Cl}^{-}$ & $\mathrm{mg} / \mathrm{L}$ & 73 & 15.32 & 0.56 & 74.09 & 73.53 & 12.63 & 0.82 \\
$\mathrm{NH}_{4}^{+}$ & $\mathrm{mg} / \mathrm{L}$ & 73 & 0.06 & 0.01 & 0.61 & 0.6 & 0.07 & 1.13 \\
$\mathrm{NO}_{2}{ }^{-}$ & $\mathrm{mg} / \mathrm{L}$ & 2 & 0.17 & 0.07 & 0.28 & 0.22 & 0.15 & 0.87 \\
$\mathrm{NO}_{3}{ }^{-}$ & $\mathrm{mg} / \mathrm{L}$ & 10 & 0.58 & 0.11 & 1.43 & 1.32 & 0.46 & 0.79 \\
$\mathrm{SO}_{4}{ }^{2-}$ & $\mathrm{mg} / \mathrm{L}$ & 73 & 1.93 & 0.37 & 15.91 & 15.54 & 2.09 & 1.09 \\
$\mathrm{Al}^{3+}$ & $\mathrm{mg} / \mathrm{L}$ & 73 & 0.6 & 0.17 & 2.66 & 2.49 & 0.66 & 1.11 \\
$\mathrm{Ba}^{2+}$ & $\mathrm{mg} / \mathrm{L}$ & 73 & 0.05 & 0.02 & 0.16 & 0.14 & 0.02 & 0.38 \\
$\mathrm{Ca}^{2+}$ & $\mathrm{mg} / \mathrm{L}$ & 73 & 4.31 & 0.52 & 27.88 & 27.36 & 3.29 & 0.76 \\
$\mathrm{Fe}^{2+3+}$ & $\mathrm{mg} / \mathrm{L}$ & 73 & 0.7 & 0.31 & 1.97 & 1.66 & 0.23 & 0.33 \\
$\mathrm{~K}^{+}$ & $\mathrm{mg} / \mathrm{L}$ & 73 & 1.74 & 0.27 & 10.9 & 10.63 & 1.23 & 0.7 \\
$\mathrm{Mg}^{2+}$ & $\mathrm{mg} / \mathrm{L}$ & 73 & 1.27 & 0.15 & 4.51 & 4.36 & 0.6 & 0.47 \\
$\mathrm{Mn}^{2+}$ & $\mathrm{mg} / \mathrm{L}$ & 73 & 0.07 & 0 & 0.44 & 0.44 & 0.09 & 1.33 \\
$\mathrm{Na}^{+}$ & $\mathrm{mg} / \mathrm{L}$ & 73 & 9.91 & 1.17 & 42.8 & 41.63 & 7.33 & 0.74 \\
$\mathrm{Si}^{+}$ & $\mathrm{mg} / \mathrm{L}$ & 73 & 2.24 & 0.44 & 6.63 & 6.19 & 0.88 & 0.39 \\
$\mathrm{Sr}^{2+}$ & $\mathrm{mg} / \mathrm{L}$ & 73 & 0.02 & 0 & 0.12 & 0.12 & 0.02 & 0.78 \\
$\mathrm{Zn}^{2+}$ & $\mathrm{mg} / \mathrm{L}$ & 73 & 0.02 & 0.01 & 0.05 & 0.04 & 0.01 & 0.27 \\
\hline & & & & & & & &
\end{tabular}

$S D$ is standard deviation, $C V$ is coefficient of variation

from the main river channel. In contrast, we found no significant longitudinal or transverse trends in principal components 2 and 3 , nor did we find a correlation with the distance from the geological substrate.

The nutrient concentrations, expressed by the variables TP and $\mathrm{PO}_{4}{ }^{3-}$, total dissolved nitrogen (TDN), and potassium $\left(\mathrm{K}^{+}\right)$, of samples from the main river channel were compared with those from the floodplain, to better understand the spatial patterns of these ecologically important elements. The concentrations of $\mathrm{PO}_{4}{ }^{3-}$, TDN, and $\mathrm{K}^{+}$were significantly higher in the main river channel than in the floodplains (t-test, $p<0.05$ ), but the concentrations of TP did not have significantly higher values in the river channel (see box plots in Fig. 6). This indicates that the floodplain generally functions as a sink for nutrients.

\section{Relationship between Hydrochemistry and Floodplain Land Cover}

The inundated area estimated from the Landsat 7 ETM+ image (17 August 2000) was ca. $855 \mathrm{~km}^{2}$. Its shape is influenced
Table 2 Principal component scores of floodwater hydrochemical variables on the three main principal component axes $(n=73)$

\begin{tabular}{llll}
\hline Variables & PC 1 & PC 2 & PC 3 \\
\hline $\mathrm{EC}$ & $\mathbf{0 . 9 3 3}$ & -0.064 & 0.023 \\
$\mathrm{pH}$ & 0.442 & -0.365 & -0.065 \\
$\mathrm{DO}$ & 0.013 & $\mathbf{- 0 . 5 4 6}$ & -0.177 \\
Alkalinity & $\mathbf{0 . 7 5 3}$ & -0.047 & -0.304 \\
$\mathrm{Al}^{3+}$ & -0.103 & -0.1 & $\mathbf{0 . 8 5 3}$ \\
$\mathrm{Ba}^{2+}$ & $\mathbf{0 . 6 0 8}$ & 0.201 & 0.197 \\
$\mathrm{Ca}^{2+}$ & $\mathbf{0 . 9 4 5}$ & 0.061 & -0.146 \\
$\mathrm{Fe}^{2+, 3+}$ & 0.335 & 0.267 & $\mathbf{0 . 5 9 3}$ \\
$\mathrm{K}^{+}$ & $\mathbf{0 . 8 2 4}$ & 0.119 & -0.151 \\
$\mathrm{Mg}^{2+}$ & $\mathbf{0 . 9 0 8}$ & 0.026 & -0.089 \\
$\mathrm{Mn}^{2+}$ & $\mathbf{0 . 5 8 9}$ & 0.336 & -0.205 \\
$\mathrm{Na}^{+}$ & $\mathbf{0 . 8 8}$ & -0.099 & 0.088 \\
$\mathrm{Si}^{+}$ & $\mathbf{0 . 7 5 8}$ & 0.03 & 0.193 \\
$\mathrm{Sr}^{2+}$ & $\mathbf{0 . 8 5 8}$ & 0.125 & 0.008 \\
$\mathrm{Zn}^{2+}$ & -0.23 & $\mathbf{0 . 7 0 1}$ & 0.067 \\
$\mathrm{TP}^{2+}$ & 0.306 & $\mathbf{0 . 6 3 7}$ & -0.243 \\
$\mathrm{PO}_{4}{ }^{2-}$ & 0.357 & $\mathbf{0 . 5 4 6}$ & -0.328 \\
$\mathrm{Cl}^{-}$ & $\mathbf{0 . 8 4}$ & -0.156 & 0.089 \\
$\mathrm{SO}_{4}{ }^{2-}$ & $\mathbf{0 . 7 1 6}$ & 0.196 & -0.308 \\
$\mathrm{TDN}^{2+}$ & 0.493 & 0.033 & 0.081 \\
$\%^{2+}$ of Variance & 43.5 & 9.9 & 8.3 \\
\hline
\end{tabular}

Scores higher than $|0.5|$ are in bold

by the topography: in low-lying areas it extends further inland (see Figs 1 and 7) and flooded areas link up with permanent water bodies in depressions (see Fig. 8).

Ten land cover types were distinguished in the lower floodplain of the Songkhram river catchment (derived from Landsat 8 OLI data, Fig. 8). The major land cover type in the floodplain is agriculture, which is reflected in the classes rice paddy culture (both rain-fed and irrigated), plantations, and bare soil. Bare soil is usually the result of rice paddy field preparation or is land that has recently been cleared for a new plantation of rubber (Hevea brasiliensis). These agricultural land cover type are highly dynamic during the year due to anthropogenic activities. The overall map accuracy was $72 \%$, as validated by randomly generating locations for each map class (330 locations in total) and comparing them with ground cover assigned by eye on the basis of the highresolution Google Earth images (see Table S1). The classification with the greatest uncertainty concerns rice paddy (45\%), which is mostly confused with the grass and herbaceous and shrub class or with the class "water". The settlement class also shows low accuracy $(50 \%)$ as it can be confused with a similarly reflecting surface of the "bare soil" class and the "grass and herbaceous and shrubs" class. The bamboo vegetation class had high classification accuracy (90\%). 

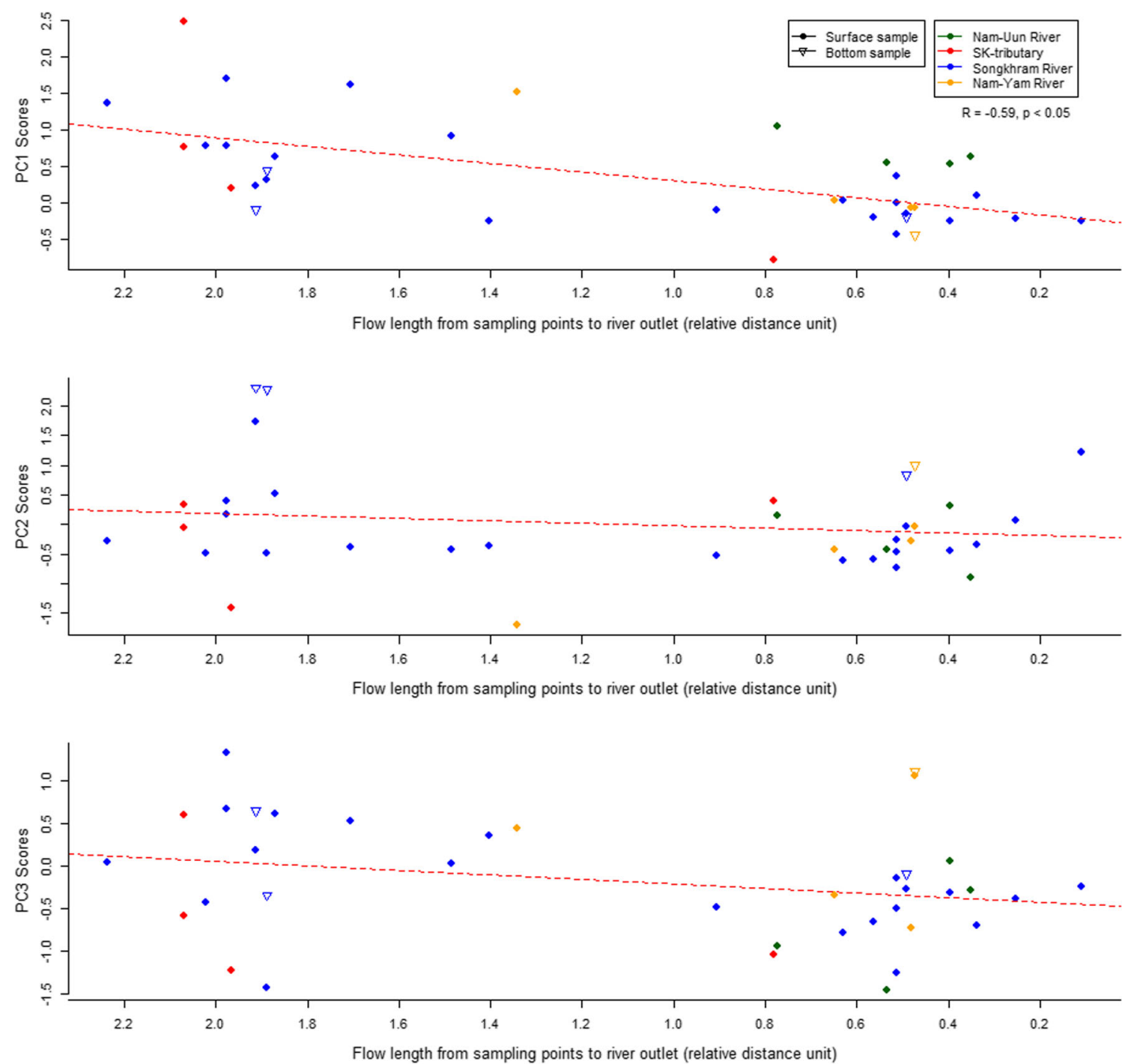

Fig. 3 Longitudinal (upstream-downstream) trends in PCA scores of river channel sampling locations. Only the first PCA component scores are significantly correlated with the distance between the sampling

Superimposing the vegetation and land cover classes on the map of inundated areas (Fig.8) revealed that the land cover accounting for the largest proportion of flooded land was agricultural: $52 \%$ of the flooded area was comprised of bare soil, irrigated and rain-fed rice paddies, and plantations. The class containing grass, herbaceous vegetation, and shrubs together occupied $20 \%$ of the flooded area. The remaining categories were open water $(9 \%)$, marsh $(8 \%)$, deciduous forest $(6 \%)$, bamboo vegetation (4\%), and settlements ( $1 \%)$.

It is clear from Fig. 8 that bamboo vegetation is found along the river channels and in most places consists of a belt of a few hundred meters wide, with a maximum width of $1200 \mathrm{~m}$. Behind the bamboo belt, the class of grass, herbaceous, and shrubs is generally present. In the field, a narrow strip of a native thorny shrub was often observed growing next to the bamboo belt, with a gradual transition to grass and location and the Songkhram catchment outlet $(r=-0.59, p<0.05)$. Surface samples taken at $30 \mathrm{~cm}$ below the water surface, bottom samples at $20 \mathrm{~cm}$ above the bottom

herbaceous vegetation. The irrigated rice paddy class was observed nearby water bodies that do not dry up in the dry season, such as lakes, oxbow lakes, and the main river channel. Rain-fed rice paddies were generally found further away from the river channel.

\section{Discussion}

\section{Longitudinal and Transverse Hydrochemical Trends}

Our sampling strategy was designed to capture the maximum spatial variability of floodwater chemistry in the river channel and floodplain. We sampled along the main river channel as well as its tributaries. The transect locations were selected to represent variability in the floodplains in the 
Fig. 4 Spatial distribution of river water scores on the first principal component shows higher scores in the upstream part of the Songkhram river and its tributaries, with lower scores in the downstream part

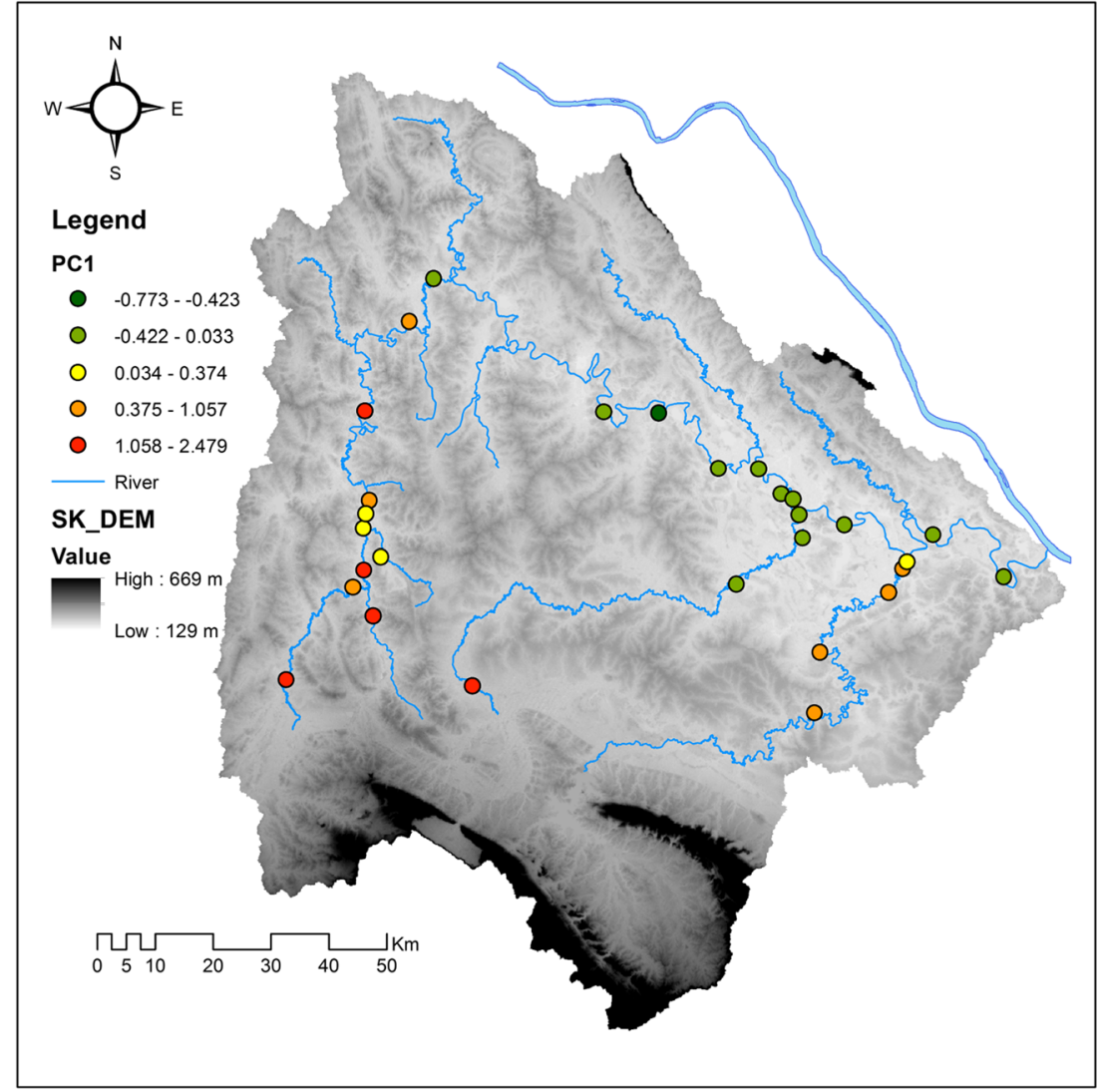

upper and lower parts of the river basin. Water chemistry is influenced by the origin of the water and by certain natural and anthropogenic factors. The following factors are relevant: the occurrence of highly soluble or easily weathered minerals; the distance from the marine environment, which controls the exponential decrease of ocean aerosols that are input to the bordering land; the aridity (precipitation/runoff ratio), which determines the concentration of dissolved substances; terrestrial primary productivity (which controls the release of nutrients); and ambient temperature. Our hydrochemical data on the Songkhram monsoon river revealed that concentrations in the river and floodplain inundation water were low. The water was poor in dissolved solids and nutrients, and slightly acid. The dominant ion concentrations were $\mathrm{Na}^{+}, \mathrm{Cl}^{-}, \mathrm{Ca}^{2+}$, and alkalinity $\left(\mathrm{HCO}_{3}{ }^{-}\right)$, which are related to the weathering products of the Songkhram river catchment geology, especially the KTms formation which is the likely source of river water sodium and chloride from rock salt, calcium and sulfate from gypsum and anhydrite, and potassium from potash. The relatively soft sandstone is a source of silica.

The EC, which is a good indicator of dissolved materials in the water, was on average $73 \mu \mathrm{S} / \mathrm{cm}$. This is much lower than the $\mathrm{EC}$ of the 3 groundwater samples we took during the fieldwork (EC average $414 \mu \mathrm{S} / \mathrm{cm}$ ). This difference can be attributed to the river water being greatly diluted during the monsoon season by the large amounts of rainfall, which has a low EC (Meybeck and Helmer 1989). Decreased solute concentrations during the monsoon have indeed been reported in a previous study of the Songkhram river (Satrawaha et al. 2009) as well as for monsoon rivers in India (Mehto and Chakrapani 2013; Kumarasamy et al. 2014; Thomas et al. 2014).

The relatively high average coefficient of variation indicates that the hydrochemistry of the floodwater of the Songkhram monsoon river and its floodplain is very variable. The longitudinal variability of hydrochemical concentrations in the Songkran River showed a decreasing trend from upstream to downstream. We relate this trend to the upstream occurrence of the geological KTMms formation with highly soluble minerals, as substantiated by the significant correlation between PC1 score and smallest distances of the sample location from the KTms formation.

The transverse hydrochemical trend revealed solute concentrations decreasing from the Songkhram river channel to its floodplain. This was evident both from the PC1 scores, which reflected the concentrations of most elements, and from the box plots, which showed significant higher concentrations in the river channel than on the floodplain for $\mathrm{PO}_{4}{ }^{3-}, \mathrm{TDN}$, and $\mathrm{K}^{+}$. We therefore conclude our hydrochemical floodwater pattern suggests a sink function of the monsoon floodplains for dissolved solids from the Songkhram river in Thailand. 

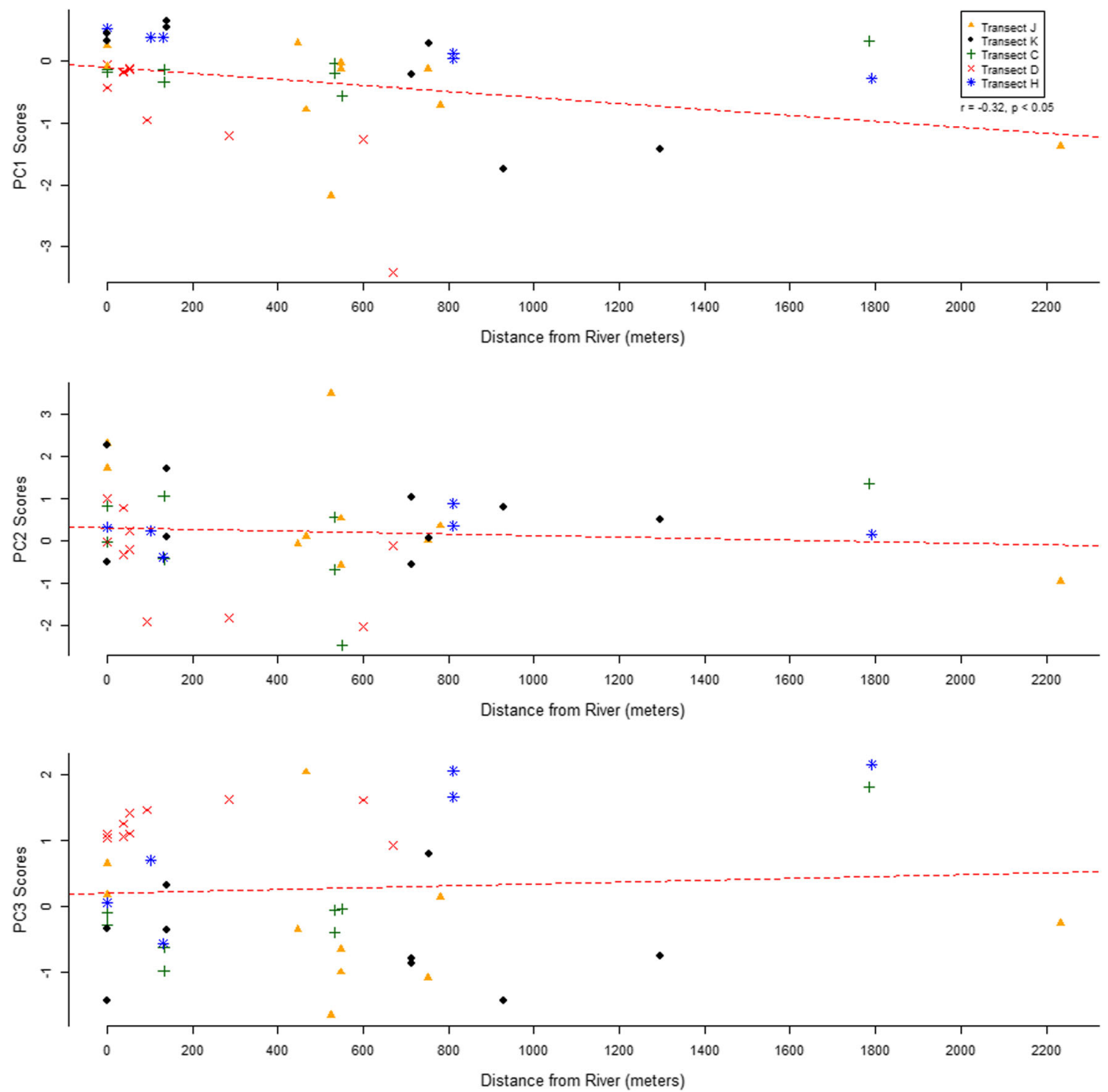

Fig. 5 Transverse trends in PCA scores of floodplain samples taken in the transects, arranged from the main river channel out into the floodplain. Only the first principal component scores (PC1) are significantly

\section{Bamboo as a Sediment and Nutrient Filter}

The water column on inundated floodplains is shallower than it is in the main river channel. This allows more light to penetrate the floodplain water column, leading to higher temperatures. These conditions favor the growth of green algae and of aquatic vascular plants in the floodplain, leading to higher productivity than in the river channel. Thus the decrease in nutrients in floodwater on the floodplain might be attributed to uptake by aquatic vegetation growing in the floodwater (Lewis et al. 2000). However, this might partly be only a temporary sink, since nutrients taken up by algae will be largely released when algae die and only the portion of the nutrients taken up by bamboo and other vascular plants may be stored into a sink for a longer time. correlated with the distance of the sampling location from the main river channel $(r=-0.32, p<0.05)$

During the classification of land cover in the flooded areas it was noted that bamboo vegetation is found in a zone immediately adjacent to the river channels. The bamboo vegetation is generally very dense, and during fieldwork, sedimentation and algae growths were observed around the bamboo stems (see Fig. 9). The clumps of bamboo along the Songkhram river reduce the velocity of floodwater, which may enable sediments in the water to settle. The bamboo is also highly productive, as evidenced by its large standing biomass. This suggests it is efficient in taking up nutrients, either directly from the floodwater or, in the dry season, from the sediment remaining after the flood. We did not find any clear data on these processes in the literature or in the field. Nonetheless, we would argue that the floodplain functions as a net sink of nutrients, mediated by highly productive bamboo. And this 

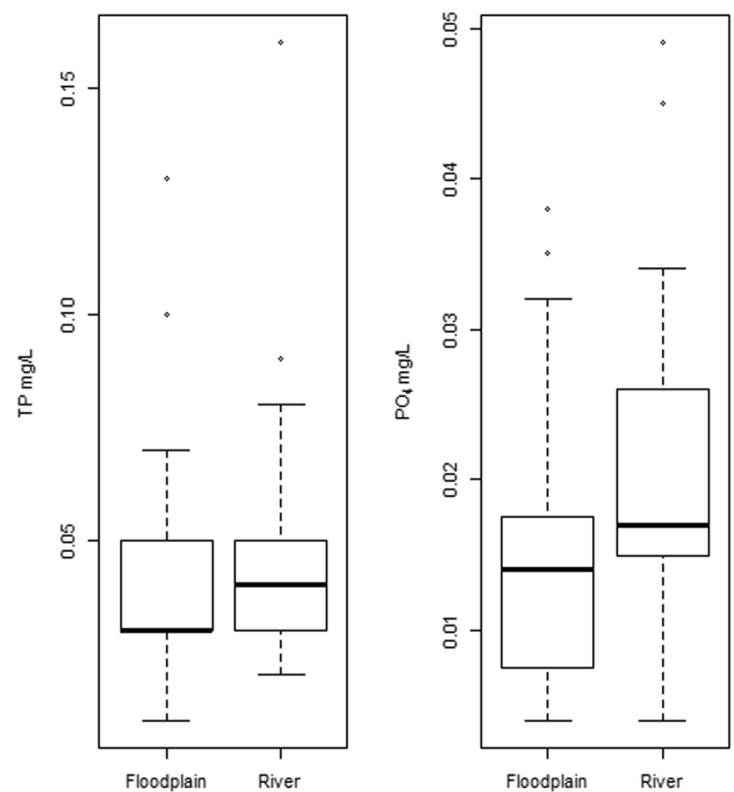

Fig. 6 Box plots of major nutrients (TP, $\mathrm{PO}_{4}{ }^{3-}, \mathrm{K}^{+}$, TDN), showing a comparison between floodplains and main river channel. $\mathrm{PO}_{4}{ }^{3-}$, TDN and $\mathrm{K}^{+}$are significantly higher in the main river channel than in the

indicates that the river is a source of nutrients and sediment for the floodplain.

Although our results show how the river and its floodplain interact in terms of hydrochemistry, we still lack a clear pattern of transport of sediment, nutrients, and organic material.
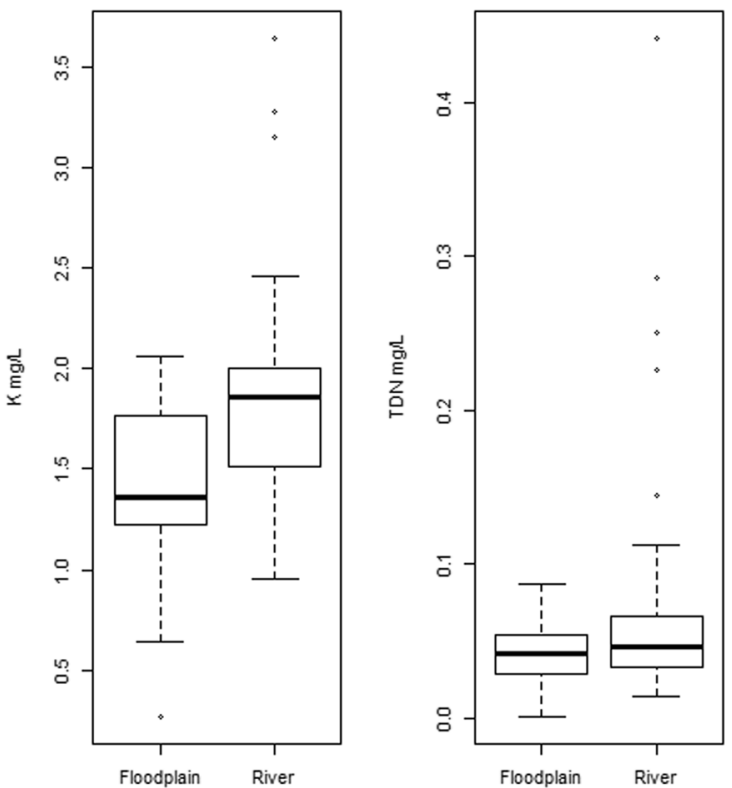

floodplains (t-test, $p<0.05)$. Each box plot represents the minimum, first quartile, median (thick horizontal line), third quartile, and maximum. Outliers are depicted by dots

Candidate topics for future research could therefore be the pathways and transformation of particulate material in the river and floodplain, as well as the temporal variation in processes affecting transport and transformation. In addition, dedicated research should test our hypothesis that the sink

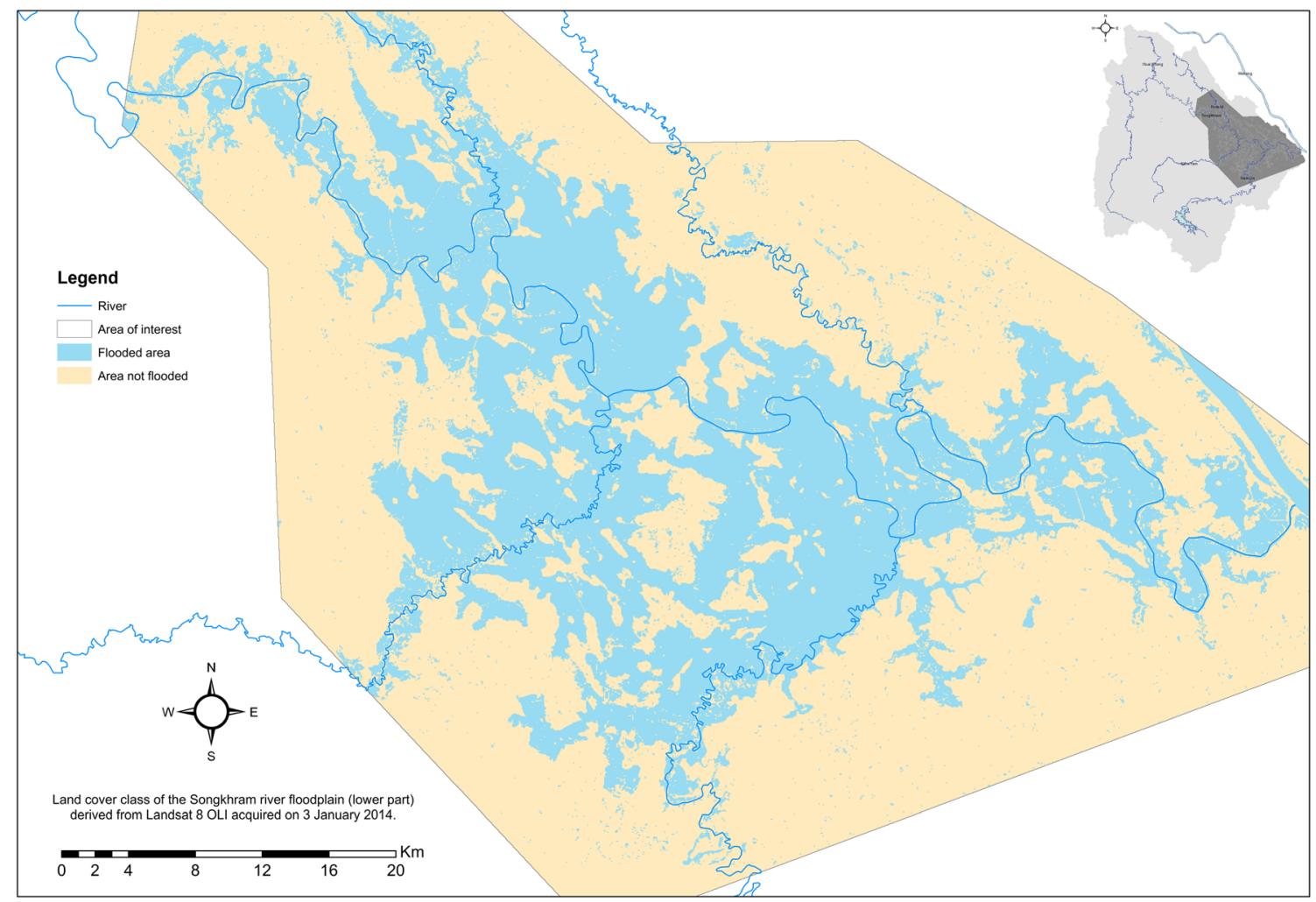

Fig. 7 Extent of flooded area in the lower basin of the Songkhram river, derived from a Landsat 7 ETM+ image of 17 August 2000 


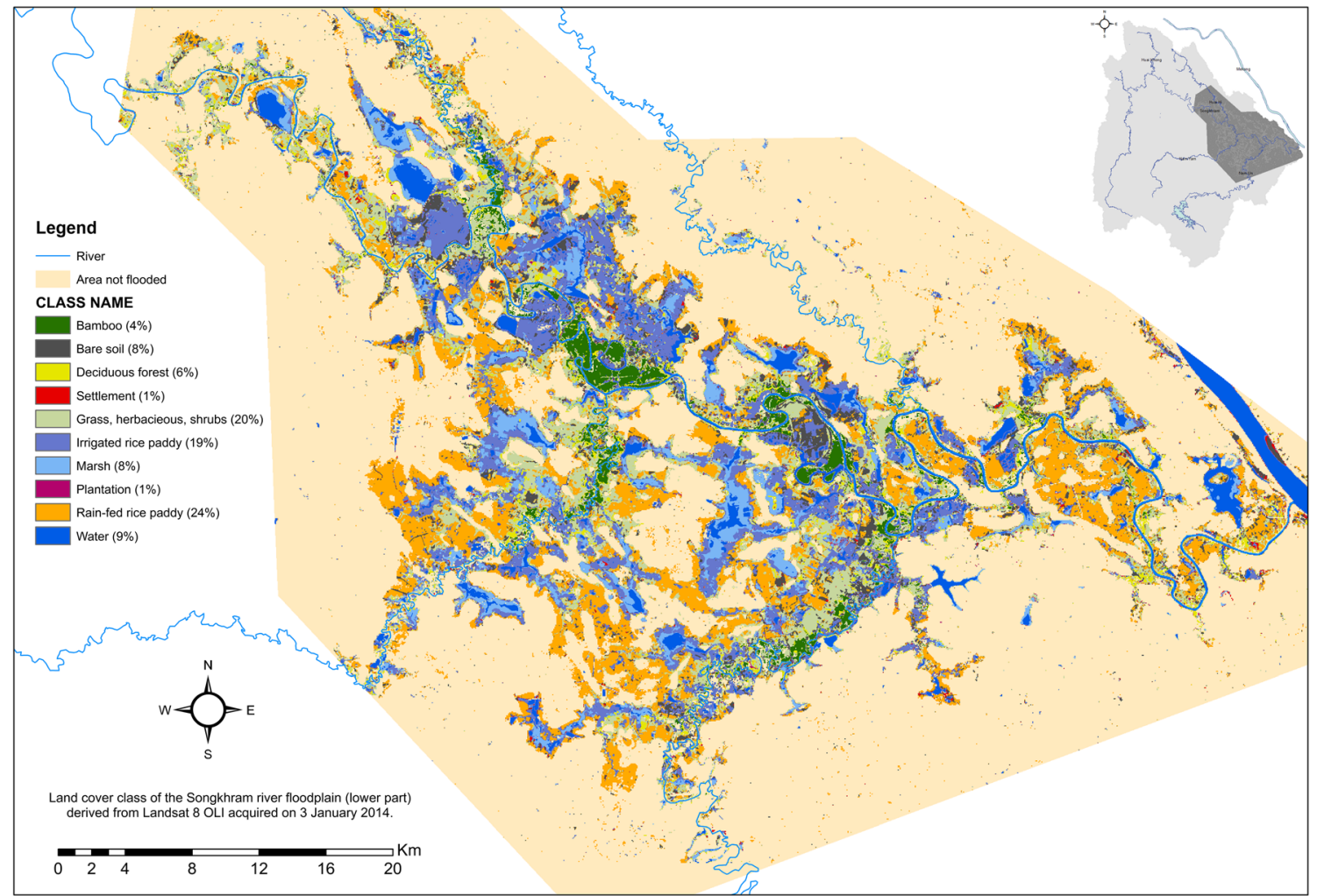

Fig. 8 Land cover classes for the flooded area in the lower basin of the Songkran River (see Fig. 7). The results have been obtained by a supervised classification with maximum likelihood method of the Landsat 8 OLI image for the dry season in January 2014

function of the Songkhram monsoon floodplain is primarily related to the presence of a bamboo strip in the floodplain, which seems to act as a sediment trap and solute filter. We suggest future analyses on sediment characteristics in the river and floodplain, as this may also be important for nutrient cycling in the aquatic system and such analyses may explain the source of $\mathrm{Fe}^{2+}, 3+$ and $\mathrm{Al}^{3+}$ and the processes steering their dissolution.

\section{Ecological and Hydrological Concepts for Monsoon River Systems}

The decreasing longitudinal trend of hydrochemical concentrations in the river during flooding as observed in our study corresponds to the physical gradient from upstream to downstream as described in the river continuum concept (Vannote et al. 1980). The limited information we gathered indicates this concept may be applicable to explain the ecological functioning of our river system. The observed decreasing trend of EC from upstream to downstream may indicate a shift in the biotic community along the river, as suggested by Jiang et al. (2011). However, in order to draw conclusions about the longitudinal ecological functioning of the monsoon river system, research needs to be done on the response of the biotic community to the hydrochemistry gradient.

The river/floodplain system we studied is also subject to transverse processes affecting the chemistry of the floodwater on the floodplain. The flood pulse concept (Junk et al. 1989), explains the ecological functioning of large river floodplain systems in terms of lateral exchange of water, sediment and
Fig. 9 Clump of bamboo with sediment accumulated around it (left: red arrow) as observed in the dry season, and occurrence of algae around bamboo as observed in wet season floodwater

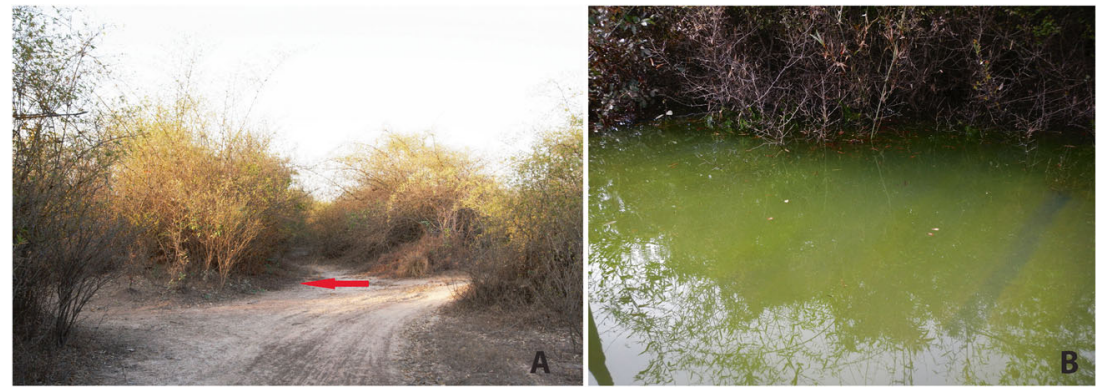


nutrients between the river and the floodplain. In our study, the river functions as a transportation route and source of dissolved material for the floodplain, including nutrients $\mathrm{PO}_{4}{ }^{3-}$, $\mathrm{TDN}$, and $\mathrm{K}^{+}$as postulated by the flood pulse concept. It is therefore likely that both concepts are applicable to explain the ecological functioning of our river system during the flood period. This is in line with the suggestion of Humphries et al. (2014), who propose the river wave concept that merges the RCC and FPC and combines it with the riverine productivity model (RPM) proposed by Thorp and Delong 1994. The RPM postulates that the river bank vegetation is highly productive due to nutrient input from the river, which may be applicable to the bamboo zone we described.

Although some general observations can be made based on our data for one monsoon river, there is a need for further data collection in monsoonal river systems to verify to what extent different river concepts also hold for river systems of this type.

Acknowledgments Many people contributed to this study during the preparation stage, fieldwork, laboratory analysis, and data processing. We thank Pinploi Sirivarikul for her fieldwork assistance in Thailand. Rojchai Satrawaha, Rachanee Nam-martra, and Panida Laotongsan from Walai Rukhavej Botanical Research institute, Mahasarakham University, Thailand are acknowledged for the fieldwork and laboratory facilities and Sathaporn Kavinate from the Department of Mineral Resources, Thailand for reviewing the geological map. We also wish to thank the Inland Aquaculture Research Institute, Department of Fisheries, Ministry of Agriculture and Cooperatives, Sakon Nakhon, Thailand for providing laboratory facilities and accommodation during the fieldwork. This research was partly supported by a grant from the Thai Government Science and Technology Scholarship Students program. Joy Burrough was the professional language editor of a near-final draft of the paper.

Open Access This article is distributed under the terms of the Creative Commons Attribution 4.0 International License (http:// creativecommons.org/licenses/by/4.0/), which permits unrestricted use, distribution, and reproduction in any medium, provided you give appropriate credit to the original author(s) and the source, provide a link to the Creative Commons license, and indicate if changes were made.

\section{References}

Arthington AH, Naiman RJ, McClain ME, Nilsson C (2010) Preserving the biodiversity and ecological services of rivers: new challenges and research opportunities. Freshwater Biology 55:1-16

Baldwin DS, Mitchell AM (2000) The effects of drying and re-flooding on the sediment and soil nutrient dynamics of lowland riverfloodplain systems: a synthesis. Regulated Rivers: Research and Management 16:457-467

Banerjee S, Secchi S, Fargione J, Polasky S, Kraft S (2013) How to sell ecosystem services: a guide for designing new markets. Frontiers in Ecology and the Environment 11:297-304

Bayley PB (1995) Understanding large river floodplain ecosystems. Bioscience 45:153-158

Beumer V, van Wirdum G, Beltman B, Griffioen J, Grootjans AP, Verhoeven JTA (2008) Geochemistry and flooding as determining factors of plant species composition in Dutch winter-flooded riverine grasslands. Science of the Total Environment 402:70-81
Blake DJH, Sunthornratana U, Promphakping B et al (2011) E-Flow in the Nam Songkhram River Basin. Mekong Program on Water Environment and Resilience. Available via DIALOG. http://www. mpowernetwork.org/Knowledge_Bank/Key_Reports/Research Reports/EFlows_in the Nam_Songkhram_River_Basin.html. Accessed 25 Sept 2014

Boulton AJ, Findlay S, Marmonier P, Stanley EH, Valett HM (1998) The functional significance of the Hyporheic zone in streams and rivers. Annual Review of Ecology and Systematics 29:59-81

Chormanski J, Okruszko T, Ignar S, Batelaan O, Rebel KT, Wassen MJ (2011) Flood mapping with remote sensing and hydrochemistry: a new method to distinguish the origin of flood water during floods. Ecological Engineering 37:1334-1349

Costanza R, d'Arge R, de Groot R, et al. (1998) The value of the world's ecosystem services and natural capital (reprinted from nature, vol 387, pg 253, 1997. Ecological Economics 25:3-15

Cushing CE, Mcintire CD, Cummins KW, Minshall GW, Petersen RC, Sedell JR, Vannote RL (1983) Relationships among chemical, physical, and biological indexes along river continua based on multivariate analyses. Archive Fur Hydrobiologie 98:317-326

Department of mineral resources (2012) Geological map of Thailand, 1:2, 500,000 . Geological survey division, department of mineral resources, Bangkok

Doering M, Uehlinger U, Tockner K (2013) Vertical hydrological exchange, and ecosystem properties and processes at two spatial scales along a floodplain river (Tagliamento, Italy). Freshwater. Science $32: 12-25$

Exelis Visual Information Solutions (2014) ENVI 5.0. Exelis Visual Information Solutions Inc., Boulder

Franklin SB, Gibson DJ, Robertson PA, Pohlmann JT, Fralish JS (1995) Parallel analysis - a method for determining significant principal components. Journal of Vegetation Science 6:99-106

Grygoruk M, Miroslaw-Swiatek D, Chrzanowska W, Ignar S (2013) How much for water? Economic assessment and mapping of floodplain water storage as a catchment-scale ecosystem Service of Wetlands. Water 5:1760-1779

Humphries P, Keckeis H, Finlayson B (2014) The river wave concept: Integrating River ecosystem models. Bioscience 64:870-882

Jiang X, Xiong J, Xie Z, Chen Y (2011) Longitudinal patterns of macroinvertebrate functional feeding groups in a Chinese river system: a test for river continuum concept (RCC. Quaternary International 244:289-295

Junk WJ, Wantzen KM (2004) The flood pulse concept: new aspects, approaches, and applications - an update. In: Welcomme RL, Petr $\mathrm{T}$ (eds) Proceedings of the second international symposium on the Management of Large Rivers for fisheries, Food and Agriculture Organization \& Mekong River Commission, vol 2. FAO Regional Office for Asia and the Pacific, Bangkok, pp. 117-149

Junk WJ, Bayley PB, Sparks RE (1989) The flood pulse concept in riverfloodplain systems. In: Dodge DP (ed) Proceedings of the International Large River Sysmposium (LARS). Canadian Special Publication of Fisheries and Aquatic Sciences 106. Ottawa, pp 110 127

Keddy PA, Fraser LH, Solomeshch AI, Junk WJ, Campbell DR, Arroyo MTK, Alho CJR (2009) Wet and wonderful: the World's largest wetlands are conservation priorities. Bioscience 59:39-51

Keizer FM, Schot PP, Okruszko T, Chormanski J, Kardel I, Wassen MJ (2014) A new look at the flood pulse concept: the (ir) relevance of the moving littoral in temperate zone rivers. Ecological Engineering 64:85-99

Khammongkol K, Trisurat Y, Duengkae P, Sungkaew S (2013) The study of riparian Forest structure in Mun River basin. [การศึกษาโครงสร้างสังคมพืชปาบุ่งปาทามในลุ่มน้ามูล/the study of riparian Forest structure in Mun River basin] Thai. Journal of Forestry 32:97-109 
Kumarasamy P, James RA, Dahms H, Byeon C, Ramesh R (2014) Multivariate water quality assessment from the Tamiraparani river basin, southern India. Environment and Earth Science 71:2441-2451

Land development Department (2014) Land used of prvinces in northeastern Thailand. Available via DIALOG. http://www.ldd.go. th/web OLP/report research NE.html. Accessed 11 June 2015

Langhans C, Govers G, Diels J (2013) Development and parameterization of an infiltration model accounting for water depth and rainfall intensity. Hydrological Processes 27:3777-3790

Lewis WM, Hamilton SK, Lasi MA, Rodríguez M, Saunders JF (2000) Ecological determinism on the Orinoco floodplain: a 15 -year study of the Orinoco floodplain shows that this productive and biotically diverse ecosystem is functionally less complex than it appears. Hydrographic and geomorphic controls induce a high degree of determinism in biogeochemical and biotic processes. Bioscience 50:681-692

Lillesand TM, Kiefer RW, Chipman JW (2008) Remote sensing and image interpretation. Willey, USA

McClain ME, Boyer EW, Dent CL, et al. (2003) Biogeochemical hot spots and hot moments at the interface of terrestrial and aquatic ecosystems. Ecosystems 6:301-312

Mehto A, Chakrapani GJ (2013) Spatio-temporal variation in the hydrochemistry of Tawa River, Central India: effect of natural and anthropogenic factors. Environmental Monitoring and Assessment 185:9789-9802

Merck KGaA (2013) 1.11109.0001 MColortest alkalinity test acid capacity to $\mathrm{pH} 8.2$ and $\mathrm{pH}$ 4.3. Merck KGaA, Darmstadt

Mertes LAK (1997) Documentation and significance of the perirheic zone on inundated floodplains. Water Resources Research 33:1749-1762

Meybeck M, Helmer R (1989) The quality of rivers - from pristine stage to global pollution. Global and Planetary Change 75:283-309

Peres-Neto PR, Jackson DA, Somers KM (2005) How many principal components? Stopping rules for determining the number of non-trivial axes revisited. Computational Statistics and Data Analysis 49:974-997

Satrawaha R, Prathepha P, Andrews R, Petney T (2009) Fundamental hydrochemical parameters of the Songkhram River in Northeast Thailand: foundation data for the study of an endangered tropical wetland ecosystem. Limnology 10:7-15

Seal Analytical (2000) Bran + Luebbe Auto Analyzer III Applications and Operation Manual. SEAL Analytical, Inc., Germany

Sedell JR, Richey JE, Swanson FJ (1989) The river continuum concept: a basis for the expected ecosystem behavior of very large rivers?. In: Dodge DP (ed) Proceedings of the International Large River Sysmposium (LARS). Canadian Special Publication of Fisheries and Aquatic Sciences 106. Ottawa, pp 49-55

Southwell M, Thoms M (2011) Patterns of nutrient concentrations across multiple floodplain surfaces in a large Dryland River system. Geographical Research 49:431-443
Steiger J, Gurnell AM (2003) Spatial hydrogeomorphological influences on sediment and nutrient deposition in riparian zones: observations from the Garonne River, France. Geomorphology 49:1-23

Thailand Royal Irrigation Department (2016) Hydrology and water management center for upper Northeastern Region - RID. Available via DIALOG. http://hydro-3.com /. Accessed 15 March 2016

Thiha SR, Wongpakam K (2012) Monitoring trends in the extent of major floods in the lower reach of Songkhram River basin, northeastern Thailand. Limnology 13:163-170

Thomas J, Joseph S, Thrivikramji KP, Manjusree TM, Arunkumar KS (2014) Seasonal variation in major ion chemistry of a tropical mountain river, the southern western Ghats, Kerala, India. Environment and Earth Science 71:2333-2351

Thorp J, Delong M (1994) The riverine productivity model - an heuristic view of carbon-sources and organic-processing in large river ecosystems. Oikos 70:305-308

Tockner K, Stanford JA (2002) Riverine flood plains: present state and future trends. Environmental Conservation 29:308-330

Tockner K, Pennetzdorfer D, Reiner N, Schiemer F, Ward JV (1999) Hydrological connectivity, and the exchange of organic matter and nutrients in a dynamic river-floodplain system (Danube, Austria. Freshwater Biology 41:521-535

Tockner K, Ward JV, Arscott DB, Edwards PJ, Kollmann J, Gurnell AM, Petts GE, Maiolini B (2003) The Tagliamento River: a model ecosystem of European importance. Aquatic Sciences 65:239-253

USGS (2006) Shuttle Radar Topography Mission, 3 Arc Second scene STRM f03 p127r048, STRM f03 p128r047, STRM f03 p128r048 filled finished 2.0, Global Land Cover Facility, University of Maryland, College Park, Maryland

USGS (2013) Using the USGS Landsat 8 Product. Available via DIALOG. http://landsat.usgs.gov/Landsat8_Using_Product.php. Accessed 25 Sept 2014

Vannote RL, Minshall GW, Cummins KW, Sedell JR, Cushing CE (1980) The river continuum concept. Canadian Journal of Fisheries and Aquatic Sciences 37:130-137

Ward JV, Tockner K (2001) Biodiversity: towards a unifying theme for river ecology. Freshwater Biology 46:807-819

Ward JV, Tockner K, Schiemer F (1999) Biodiversity of floodplain river ecosystems: Ecotones and connectivity. Regulated Rivers: Research and Management 15:125-139

Ward JV, Tockner K, Aroscott DB, Claret C (2002) Riverine landscape diversity. Freshwater Biology 47:517-539

Wassen MJ, Joosten JHJ (1996) In search of a hydrological explanation for vegetation changes along a fen gradient in the Biebrza Upper Basin (Poland). Vegetatio 124:191-209

YSI Environmental (2009) YSI 556 MPS Multi Probe System, Operations Manual . Available via DIALOG. http://www.ysi. com/media/pdfs/655279-YSI-556-Operations-Manual-RevD.pdf. Accessed 25 Dec 2014 